\title{
The Roles of Farmers in Agricultural Development
}

\author{
Nguyen Thu Thuy \\ Faculty of Economics, \\ School of Economics and Business Administration \\ Thai Nguyen University \\ Email: thuthuytn1211@gmail.com \\ Vietnam \\ Ma Thi Huyen Nga \\ Faculty of Economics \\ School of Economics and Business Administration \\ Thai Nguyen University \\ Email: huyennga@gmail.com \\ Vietnam \\ Vu Bach Diep \\ Faculty of Economics \\ School of Economics and Business Administration \\ Thai Nguyen University \\ Email: vubachdiep@gmail.com \\ Vietnam
}

\section{ABSTRACT}

To study the factors affecting people's participation in the development of agricultural value chains, the research team collected information from 230 samples in some northern mountainous provinces of Vietnam. The article uses the EFA model and Probit model to conduct the analysis. By using the EFA model and the Probit model to assess the factors affecting farmers' participation in the development of the value chain, our findings show factors: income, natural conditions, loan capital, market have a great impact on the level of people's participation. The article has suggested some solutions to improve people's participation in agricultural value chain development.

\section{Keywords: agricultural products, value chain, production link.}

\section{JEL: Q12, Q17}

\section{Introduction}

Linking production with the consumption of agricultural products plays a very important role in agricultural development, helping to improve the benefits of value chain actors, especially farmers. Farmers are the leading force in product innovation, the subject of the chain linking the production and consumption of agricultural products. In the link chain, the role of the producer is very important determining the success. Their initiative in participating in building chain links is important, which contributes to increasing the scale of goods production, applying modern production processes, and improving management capacity. All these factors are to avoid the situation of "good season, devaluation".

Farmers in the northern mountainous provinces have begun to participate in the value chain of local agricultural products. Due to the differences in qualifications, capacity, capital, and scale, the level of participation in the value chain and success is not the same, therefore, farmers must equip themselves with knowledge about production, market, gradually converting to large-scale production... At the same time, farmers need to equip themselves with legal knowledge to protect their interests in the process of association. In particular, farmers need to have a strategy and jointly bear the risks with the associated object. The assessment of the influence of factors on the participation of farmers in the development of agricultural value chains in the Northern mountainous region will help people and authorities to have appropriate orientations and solutions. This is to increase the level of people's participation in the value chain contributing to sustainable agricultural development.

\section{Research literature review}

First, "value chain refers to the activities required to bring a product or service from conception, through various stages of production to distribution to the final consumer and disposition after use" (Kaplinsky, 1999). Renewing linkages in production and consumption of agricultural products among actors under the market mechanism to enhance added value along the agricultural product value chain (Tran Gia Long, 2013).

Alice (2016) said that in the agricultural production sector, the accessibility of agents faces many difficulties due to 


\author{
E-ISSN: 2469-6501 \\ VOL: 7, ISSUE: 12 \\ December/2021 \\ DOI: http://dx.doi.org/10.33642/ijbass.v7n12p4 \\ (c) $\underset{\mathrm{EY}}{\mathrm{i}}$ \\ https://creativecommons.org/licenses/by/4.0/
}

the lack of collateral; lack of guarantors, lack of customer information and unclear business plans, high loan interest rates. Therefore, actors often hesitate before deciding to borrow capital. This greatly affects the production plan. Kalunda's study (2014) also showed that age and gender greatly influence the decision to borrow. In addition, agricultural production is often distributed in places where the industrial economy is less developed. The most difficult infrastructure is communication. Therefore, credit services, especially microcredit, which provides preferential credit to the people, need to be developed. Attention should be paid to customers in areas where there are many difficulties in the production and consumption of products, Tshabangu (2013).

Wang, $X$ et al. (2021) The value chain comprises several factors and activities useful for strengthening production and distribution by connecting producers with suppliers, intermediaries, and marketplaces and collaboratively creating added value for products or goods. However, the values of agricultural products mostly depend on various factors and actors, which should be linked together for fostering added values. Thus, there may be strong ground for facilitating a smooth transition of the agricultural value chain (AVC) within the prospects of emerging countries. It could be a key means of promoting a profound connection between smallholder farmers and modern agriculture facilities. It could be especially crucial for highly perishable and high-value products such as fruits. Fruit farmers' gender, total household expenditure, housing value, planting scale, planting years, degree of specialization, days of family labor input, and total days of employment have significant effects on their participation in AVC activities. (2) Fruit farmers' usage of improved fertilizers and organization participation supports a higher yield and net income per acre. (3) Participating in two kinds of AVC can significantly improve the yield per acre and net income per acre compared with only using one type of AVC (improved fertilizer). Policymakers should improve the existing policy by eliminating institutional barriers and enhancing human factors for farmers to participate in highvalue chain activities. Governments should extend technical support, and enhance training facilities, and comprehensively promote the AVC among smallholder farmers.

Finally, farmers' organizations (e.g., cooperatives and credit organizations) should come forward to help facilitate the effectiveness of AVC.

And Kumari et al (2021) showed agriculture value chains (AVCs) have experienced unprecedented disruption during the COVID-19 pandemic, with lockdowns and stringent social distancing restrictions making buying and selling behaviors complex and uncertain.

\section{Research Methods}

In the study, the authors used the EFA model and the Probit model to assess the factors affecting farmers' participation in the development of the value chain.

The research team used the non-randomly selected sampling survey method, the sample size determination was consistent with the data analysis method. The article uses the method of Tabachnick \& Fidell (2005) to calculate the appropriate sample size, according to which the sample size must satisfy the formula $\mathrm{n} \geq 8 \mathrm{~m}+50$. With 20 observations in the survey, the minimum sample size is 210 With 14 provinces in the region, the authors will choose to investigate 3 provinces with specific economic characteristics, agricultural development resources, and development levels, including Bac Kan, Son La, Tuyen Quang.

Method of investigation: face-to-face interview. The number of tickets given out was 250 , the number of valid votes collected was 230 .

\title{
Proposing a research model
}

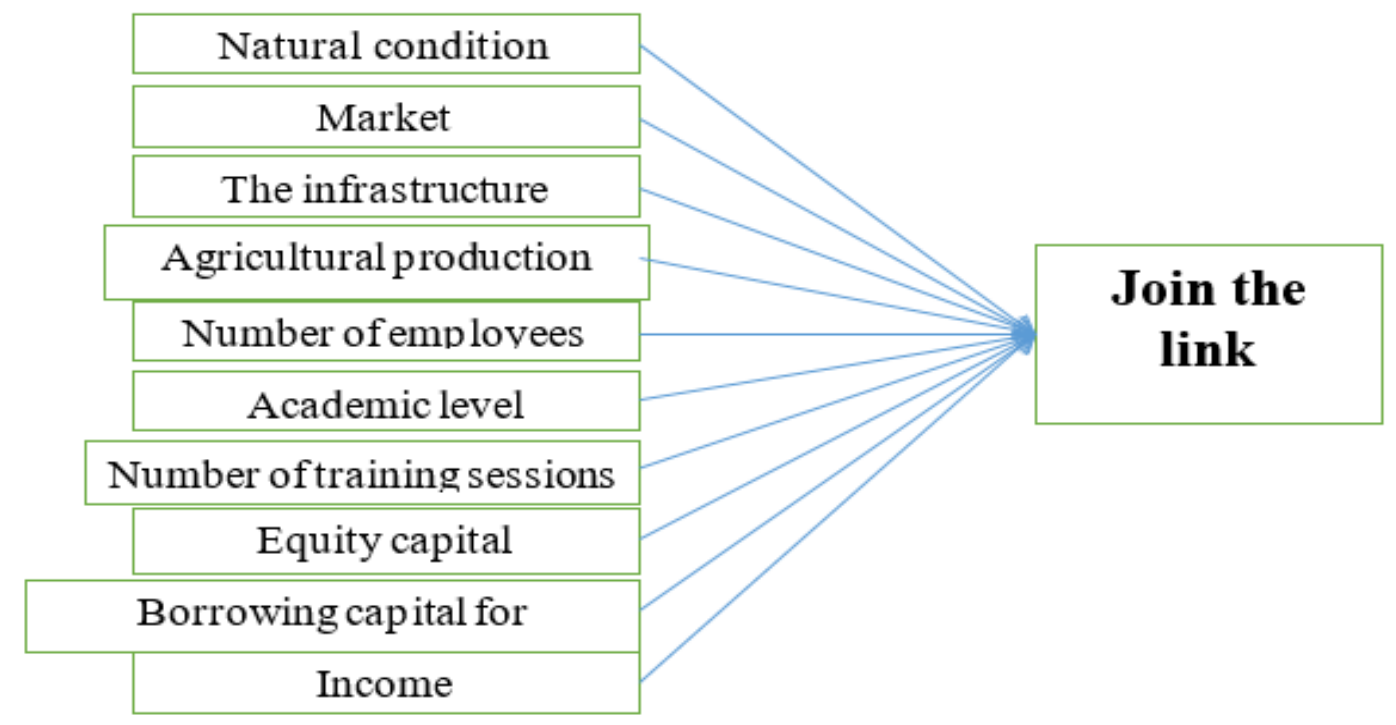

Figure 3.1. Factors affecting the level of people's participation in value chain linkage

Source: Synthesis of the research team, 2020 
VOL: 7, ISSUE: 12

December/2021

DOI: http://dx.doi.org/10.33642/ijbass.v7n12p4

Table 3.1. Interpretation of observed variables in the research model

\begin{tabular}{|c|c|c|}
\hline & Variable nam & Expectation sign \\
\hline Natus & ditions (TN) are used Liket scale from 1 to 5 & \\
\hline TN1 & Weather conditions (rain, humidity, temperature) & \\
\hline TN2 & Natural disaster & + \\
\hline TN3 & Due to insect pests & \\
\hline Mark & is used Liket scale from 1 to 5 & \\
\hline TT1 & Precarious prices & \\
\hline TT2 & No big market yet & + \\
\hline TT3 & Little information about the market & + \\
\hline TT4 & Simple transaction method & \\
\hline Infra: & re (HT) is used Liket scale from 1 to 5 & \\
\hline HT1 & Difficult travel conditions & \\
\hline HT2 & Limit contact information & \\
\hline HT3 & Small market system & + \\
\hline HT4 & Limited production auxiliary grid power system & \\
\hline Area: & Ired in $\mathrm{m}^{2}$ the number of agricultural production areas of households & + \\
\hline Labo & ber of employees involved in production of the household & + \\
\hline Educ & vel: years of schooling of the household head (years) & + \\
\hline $\begin{array}{l}\text { Num2 } \\
\text { mem }\end{array}$ & $\begin{array}{l}\text { raining sessions: measured by the number of times the household head or } \\
\text { nded (times) }\end{array}$ & + \\
\hline $\begin{array}{l}\text { Finar } \\
\text { VND }\end{array}$ & pacity: own capital to participate in agricultural production (million & + \\
\hline $\begin{array}{l}\text { Borrc } \\
\text { produ }\end{array}$ & The author uses dummy variables. 0 : if no bank loan, 1 : bank loan to serve & \\
\hline Incon & ome situation of farmer households & + \\
\hline
\end{tabular}

Source: Synthesis of the research team, 2020

\section{Research results}

Cronbach's Alpha test results

The research results show that the Cronbach's Alpha data are suitable for conducting EFA analysis. Besides, we coefficient for the scale of the largest components is 0.858 and have the P-value of Bartlett's test equal to 0 , the variables are the smallest is 0.734. Thus, all Cronbach's Alpha coefficients correlated with each other in terms of the population. are greater than 0.6 and the variables have total correlation coefficients less than 0.3. Thus, the variables ensure the requirements for conducting exploratory factor analysis (EFA).
Result of factor analysis (EFA)

The KMO coefficient is 0.811 , which indicates that the

By exploratory factor analysis EFA, the extracted variance reached $62.025 \%$, which means that the extracted factor explained $64.131 \%$ of the variation.

Table 3.2. Result of factor rotation

\begin{tabular}{|c|c|c|c|}
\hline & \multicolumn{3}{|c|}{ Component } \\
\hline & 1 & 2 & 3 \\
\hline HT2 & 883 & & \\
\hline HT1 & 876 & & \\
\hline HT3 & 847 & & \\
\hline HT4 & .682 & & \\
\hline TT4 & & .794 & \\
\hline TT1 & & .746 & \\
\hline TT2 & & .734 & \\
\hline TT3 & & .717 & \\
\hline TN1 & & & 819 \\
\hline TN2 & & &, 786 \\
\hline TN3 & & & 648 \\
\hline
\end{tabular}


After using the EFA model to group factors, the results are as follows:

The first group of factors includes observed variables HT2, HT1, HT3, HT4. The infrastructure factor is relatively concentrated in the assessment (Denoted as HT).

The second group of factors includes the observed variables TT4, TT1, TT2, TT3. The market factor is relatively concentrated in the assessment (denoted by TT).

Table 3.3. Regression results

\begin{tabular}{|c|c|c|c|}
\hline Independent & $\begin{array}{c}\text { Regression } \\
\text { coefficient } \\
(\boldsymbol{\beta})\end{array}$ & $\begin{array}{c}\text { Marginal impact } \\
\mathbf{( d y / d x )}\end{array}$ & $\begin{array}{c}\text { The P-value of the } \\
\text { marginal effect factor }\end{array}$ \\
\hline TN & 0,4328 & 0,1681 & 0,002 \\
\hline TT & 0,3174 & 0,1233 & 0,009 \\
\hline HT & 0,2987 & 0,1160 & 0,052 \\
\hline DT & 0,0017 & 0,0006 & 0,002 \\
\hline KN & 0,0100 & 0,0038 & 0,361 \\
\hline TD & 0,1292 & 0,0502 & 0,000 \\
\hline TH & 0,0681 & 0,0264 & 0,002 \\
\hline TC & 0,2091 & 0,0812 & 0,020 \\
\hline VV & 0,3818 & 0,1478 & 0,055 \\
\hline IC & 0,4637 & 0,1537 & 0,047 \\
\hline
\end{tabular}

Source: Synthesis of the research team, 2020

Check the phenomenon of self-multicollinearity: Research using VIF coefficients, the results show that these coefficients are all less than 2. Thus, there is no multicollinearity phenomenon.

\section{Discussion}

The third group of factors includes TN1, TN2, TN3. This group is also relatively concentrated (Denoted as TN).

\section{Research results}

After evaluating the convergence of the variables measured by the Likert scale through the EFA model, the authors carried out the regression of the factors according to the Probit model and got the following results. 


\author{
E-ISSN: 2469-6501 \\ VOL: 7, ISSUE: 12 \\ December/2021 \\ DOI: http://dx.doi.org/10.33642/ijbass.v7n12p4 \\ (c) $\underset{\mathrm{EY}}{\mathrm{i}}$ \\ https://creativecommons.org/licenses/by/4.0/
}

Infrastructure: The infrastructure in the area is still focal points to consume products, so households often choose limited due to the lack of diverse terrain and investment these units for consumption. Difficult infrastructural conditions capital, so it is difficult to transport goods to the centers of are also the reason for limiting linkages in the consumption of buying and selling agricultural products. Enterprises and agricultural products.

traders have conditions for means of transport and have many

Table 3.6. Infrastructure Assessment

\begin{tabular}{|l|r|r|r|r|}
\hline & Minimum & Maximum & Mean & Std. Deviation \\
\hline HT & 4,0 & 5,0 & 4,325 &, 4163 \\
\hline
\end{tabular}

Source: Synthesis of the research team, 2020

Area: For agricultural products of the Northern agriculture. Agriculture is influenced by many objective and mountainous region, the production and expansion of subjective factors. Therefore, an increase in people's income production area still face many difficulties: Production has not will play a role in promoting people's participation in value yet had a specific plan; People still mainly produce chain linkages, and the opposite is also true. If increased spontaneously, so there is an oversupply or a shortage of linkages will help people's incomes increase, from which supply; The price of agricultural products is volatile, which people will have more motivation to invest and expand greatly affects people's income.

Education and training: these are two variables that have a great influence on the application of science and technology to the production of crops and livestock that are suitable for localities. The survey data shows that the educational level of households is at level 1. Many households are illiterate and live in remote areas of the provinces in the northern mountainous region, which leads to the application of Using and deploying science and technology to the people is very difficult. Besides, people still keep traditional production methods, especially outdated production practices. This is also one of the great difficulties for state officials in implementing documents and guiding people to live and produce in modern ways.

Loans: Loans are a very important input source in the production process of households. Loan channels of Bac Kan, Son La, Tuyen Quang farmers are relatively simple. Due to low loans, it is limited in the production of agricultural products in the direction of people's goods.

Income: The general level of income of people in the production.

\title{
6. Conclusion
}

Conduct an assessment of the factors affecting people's participation in the development of value chains in the Northern mountainous region, Vietnam. The research team found that there are many major influencing factors including income, natural conditions, loans, markets, infrastructure... These factors have a positive impact on mindset change, production habits, and orientations of farmers. Therefore, to improve the level of people's participation in value chain development shortly, the research team suggests many related policies, including Building a market promotion mechanism in the region such as Development of OCOP products; Trade investment promotion; Expanding the regional consumption association market; Introduce agricultural products to international markets...; It is necessary to upgrade and repair the transport system; Build and repair traditional markets and farmers' markets so that people can easily consume products; Expanding loan forms, diversifying loan sources and simplifying loan procedures. northern mountainous area is low and mainly comes from

\section{REFERENCES}

A.J. Johnson, C.C. Dibrell, E. Hansen (2009), Market orientation, innovativeness, and performance of food companies, Journal of Agribusiness, 27 (1/2) (2009), pp. 85-106

Bui Thi Thom et al. (2021). Improving Yield and Quality of Wild Pork and Pigs in Thai Nguyen, Vietnam - and Solutions to Enhance Competitiveness to Thailand and China, Alinteri Journal of Agriculture Science, 36(1).

Bui Thi Suu et al. (2021). The Auto-infection Trap with the Native Entomopathogenic Fungus, Beauveria Bassiana for Management of Coffee Berry Borer (Stephanoderes Hampei Ferrari) in the Northwest Region of Vietnam, Alinteri Journal of Agriculture science, 36(1).

C. Rosenzweig, F.N. Tubiello, R. Goldberg, E. Mills, J. Bloomfield (2002) Increased crop damage in the US from excess precipitation under climate change Global Environ. Change, 12 (2002), pp. 197-202.

Fulbright Economics Curriculum. Analysis of value chains and agricultural commodities. 2012-2014 school year.

David B. Lobell, Marshall B. Burke, Claudia Tebaldi, Michael D. Mastrandrea, Walter P. Falcon, Rosamond L. Naylor (2008), Prioritizing Climate Change Adaptation Needs for Food Security in 2030, Science, Vol. 319, Issue 5863, pp. 607-610, USA. 


\author{
E-ISSN: 2469-6501 \\ VOL: 7, ISSUE: 12 \\ December/2021 \\ DOI: http://dx.doi.org/10.33642/ijbass.v7n12p4 \\ (c) $\underset{\mathrm{EY}}{\mathrm{i}}$ \\ https://creativecommons.org/licenses/by/4.0/
}

E. Hansen, C. Dibrell, J. Down (2006), Market orientation, strategy, and performance in the primary forest industry, Forest Science, 52 (3) (2006), pp. 209-220.

Ha, T.T.H, Khoa, N.B., Huy, D.T.N., Nhan, V.K., Nhung, D.H., Anh, P.T., Duy, P.K. (2020). Modern Corporate Governance Standards and Role of Auditing-Cases in Some Western European Countries After Financial Crisis, Corporate Scandals and Manipulation, International Journal of Entrepreneurship, 23(1S).

Huy, D. T.N., Dat, P. M., và Anh, P. T. (2020). 'Building and econometric model of selected factors' impact on stock price: a case study', Journal of Security and Sustainability Issues, vol.9(M), pp. 77-93. https://doi.org/10.9770/jssi.2020.9.M(7)

Huy D.T.N., Nhan V.K., Bich N.T.N., Hong N.T.P., Chung N.T., Huy P.Q. (2021). 'Impacts of Internal and External Macroeconomic Factors on Firm Stock Price in an Expansion Econometric model-A Case in Vietnam Real Estate Industry', Data Science for Financial Econometrics-Studies in Computational Intelligence, vol.898, Springer. http://doi-org-443.webvpn.fjmu.edu.cn/10.1007/978-3-030-48853-6_14

Kalunda, E (2014), Financial Inclusion Impact on Small-Scale Tea Farmers in Nyeri County, Kenya, World Journal of Social Sciences Vol. 4. No. 1. March 2014 Issue. Pp. 130 - 139

Kwizera Alice (2016), Master thesis: "Impact of Agricultural Value Chain Financingo Smallholder Farmers' Livelihoods", University of Rwanda, College of Business and Economics, Rwanda.

Kumari, S., Venkatesh, V.G., Deakins, E., Mani, V. and Kamble, S. (2021), "Agriculture value chain sustainability during COVID-19: an emerging economy perspective", The International Journal of Logistics Management, Vol. ahead-ofprint. https://doi.org/10.1108/IJLM-04-2021-0247

Lan, N.T.N. et al. (2020). Enhancing Roles of Management Accounting and Issues of Applying IFRS for Sustainable Business Growth: a Case Study, Journal of Security and Sustainability Issues, 10(2): 709-720.

https://doi.org/10.9770/jssi.2020.10.2(27)

Ly Thi Hue, Nguyen Thu Thuy, Dinh Tran Ngoc Huy, Le Ngoc Nuong, Nguyet Viet Binh, Dam Thi Thanh Huyen, Nguyen Thi Minh Thao. (2021). Factors Affecting the Access to Bank Credit of SMEs in Northeastern Region, Vietnam, International Journal of Entrepreneurship, 24(Special issue 2).

N.A. Aziz, N.M. Yassin (2010), How will market orientation and external environment influence the performance among SMEs in the agro-food sector in Malaysia? International Business Research, 3 (3) (2010), pp. 154-164

Nguyen Thi Quynh Huong et al. (2021). Factors Affecting The Decisions Of Local People To Participate In Community Tourism In The North West of Vietnam, DINH TRAN NGOC HUY NGUYEN THI TU Journal of Contemporary Issues in Business and Government, 27(2): 226-232. 10.47750/cibg.2021.27.02.028

Nguyen Van Dat et al. (2021). Improving Tourism Entrepreneur's Competition during the COVID 19 Pandemic - A Case Study in Tourism Industry in Vietnam, Revista Geintec-Gestao Inovacao E Tecnologias, 11(3).

Nhung, D.H. et al. (2020). A Formal and Informal Rural Credit Accessibility of Ethnic Minority Households: Empirical Study in Vietnam, International Journal of Entrepreneurship, 23(1S).

N. Koide, A.W. Robertson, A.V.M. Ines, J.-H. Qian, D.G. DeWitt, A. Lucero (2013) Prediction of rice production in the Philippines using seasonal climate forecasts J. Appl. Meteorol. Climatol., 52 (2013), pp. 552-569.

Raphael Kaplinsky and Mike Morris. (2001). A Handbook for Value Chain Research. United Kingdom. Institute of Development Studies. University of Sussex.

T.L. Baker, P.M. Simpson, J.A. Siguaw (1999), The impact of suppliers' perceptions of reseller market orientation on key relationship constructs, Journal of the Academy of Marketing Science, 27 (1) (1999), pp. 50-57.

Tran Gia Long (2013), "Innovation of linkages in production and consumption of agricultural products among actors under the market mechanism to increase added value along the agricultural product value chain", Development Economics Journal, pages 13-28

Wang, X.; Sarkar, A.; Wang, H.; Zhang, F. (2021). Does Participation in Agricultural Value Chain Activities Inlfluence Smallholder Fruit Grower Production Performance? A Cross-Sectional Study of Apple Farmers in Shandong, China. Horticulturae, 7, 153. https://doi.org/10.3390/horticulturae7060153 